\title{
24. Crystal Structure of (-)-Corycavinium (+)-10-Camphorsulfonate, a Biosynthetic Intermediate to Hexahydrobenzo[c]phenanthridine Alkaloids
}

\author{
by Miyoko Kamigauchi*, Yuko Noda, Kinuko Iwasa, and Zjujiro Nishijo \\ Kobe Women's College of Pharmacy, Motoyamakita-machi, Higashinada-ku, Kobe 658, Japan \\ and Toshimasa Ishida and Yasuko In \\ Osaka University of Pharmaceutical Sciences, Kawai, Matsubara 580, Japan \\ and Wolfgang Wiegrebe \\ Faculty of Chemistry and Pharmacy, Regensburg University, P.O. Box 387, D-93000 Regensburg
}

(19.X.93)

\begin{abstract}
The crystal structure of (-)-corycavinium (+)-10-camphorsulfonate has been investigated by X-ray analysis. The structure of (-)-corycavinium ion $(=(-)-(7 S, 13 S, 14 R)-5,6,13,13 a-t e t r a h y d r o-13 a-h y d r o x y-7-m e t h y l-$ $2,3 ; 9,10$-bis(methylenedioxy)- $8 H$-dibenzo[ $a, g]$ quinolizinium), has been determined. The conformation with $B / C$ cis-conjunction, a twisted half-chair of ring $\mathrm{B}$, and a half-chair of ring $\mathrm{C}$, as well as $\alpha$-oriented substituted groups $\mathrm{N} \cdots \mathrm{Me}, \mathrm{C} \cdots \mathrm{Me}$, and $\mathrm{C} \cdots \mathrm{OH}$ is revealed. Feeding experiments with cell suspension cultures of Corydalis incisa (Papaveraceae) defined the intermediacy of (-)-corycavinium in the route from protoberberine-type to hexahydrobenzo[ $c]$ phenanthridine-type of alkaloids. On the basis of the present crystal conformation, the stereospecificity of the relating enzyme is biogenetically considered.
\end{abstract}

Introduction. - Since 1867, there have been chemical studies [1] of protopine-type alkaloids, produced by all papaveraceae spp., with contemporary efforts focussed on this group's biosynthetical behavior [2-5]. Protopine-type alkaloids function as key intermediates in the metabolism of the protoberberine type (Scheme 1).

The structural formulas of protopine-type alkaloids are commonly described as 'free base form (a)' in which ring $B$ is a ten-membered ring with a tertiary $\mathrm{N}$-atom. They are so-called, because this type of alkaloids are conventionally isolated under conditions of a strongly alkaline solution from an extract of papaveraceae plants. Though the chemically isolated form of this type alkaloid is the tertiary free-base form a, the quarternary form may be essential under the living-cell condition, the presence of free base form a being impossible in the cytoplasm of a plant cell, owing to its poor solubility. Three forms are possible structures for the quarternary form of protopine-type alkaloids; i.e., protonated type 'protonated form (b)', cis-ring-closure type 'protopinium form $\left(\mathbf{c}_{c i s}\right)$ ', and trans-ringclosure type 'protopinium form ( $\mathbf{c}_{\text {trans }}$ ').

Although use of spectroscopic methods such as CD, IR, and NMR has been proven for the conformational study of the tertiary-amine form of alkaloids, it is not so useful for the quarternary amine form, when it is the salt of protopine-type alkaloids. This problem may be due to the use of polar solvents in measuring the spectra of the structures possessing the ionic bonding. Consequently, while the importance of protopine-type alkaloids is now well known, studies involving the protopinium form, which give a well-defined conclusion, are limited to the use of X-ray analysis [6]. 
Scheme 1. The Biosynthetic Pathway from Protoberberine-Type via Protopine-Type to the Other Tipes in Papaveraceae<smiles>c1ccc2c(c1)CCN1Cc3ccccc3C2C1</smiles>

Protoberberine type

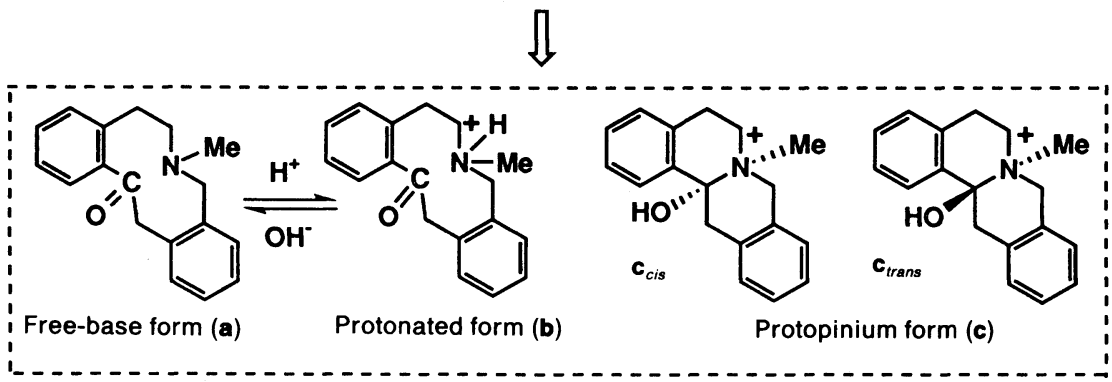

Protopine type<smiles>C=Cc1ccccc1</smiles><smiles>C[n+]1cc2ccccc2c2ccc3ccccc3c21</smiles>

Benzo[c]phenanthridine type<smiles>CN1CCc2ccccc2C12Cc1ccccc1C2=O</smiles>

Spirobenzylisoquinoline type<smiles>CN1CCc2ccccc2C2c3ccccc3C(=O)C21</smiles>

Benzindanoazepine type

Our previous results in biosynthetic studies [4] [5] suggested that the O-containing functional group on the structure may play an important role in a $\mathrm{C}(6)-\mathrm{N}(7), \mathrm{C}(8)-\mathrm{N}(7)$, and $\mathrm{C}(14)-\mathrm{N}(7)$ bond cleavage for further metabolites in the pathway of protoberberine alkaloids. The accumulation of the steric molecular structure for salt forms of protopinetype alkaloids, particularly at $\mathrm{C}(14)-\mathrm{N}(7)$ moiety, may tell us what kind of enzymatic reaction mechanism is taking place at the ring-formation stage.

The present investigation was undertaken by X-ray analysis to clarify the steric structure of (-)-corycavinium (1c) salt, which is one of the protopine-type alkaloids, and by means of feeding experiments to confirm this compound as a key intermediate to the hexahydrobenzo[ $[c]$ phenanthridine-type alkaloids, (+)- and (-)- corynoline (2), and (+)14-epicorynoline (3), etc.

Results and Discussion. - $X$-Ray Analysis. In solution or in solid state, the free base form $\mathbf{a}$ of (-)-corycavine (1a) gives rise relatively easily to a racemate by epimerization of an asymmetric $\mathrm{C}$-atom. This is because the atom is located in the 13 position adjacent to a $\mathrm{C}=\mathrm{O}$ group in the structure [7-9]. This racemization of optically active corycavine (1a) also arises, when common procedures are applied for its isolation from the plants. 
Consequently, to obtain $100 \%$ optically pure corycavine (1a), it is necessary to employ an operation of purification by functional recrystallization of the diastereoisomeric salts with (+)-10-camphorsulfonic acid, and this salt form is useful for avoiding racemization.

A perspective drawing with the numbering schemes of (-)-corycavinium (1c) (+)-10camphorsulfonate structure, obtained by X-ray crystal analysis, is shown in Fig. 1 .
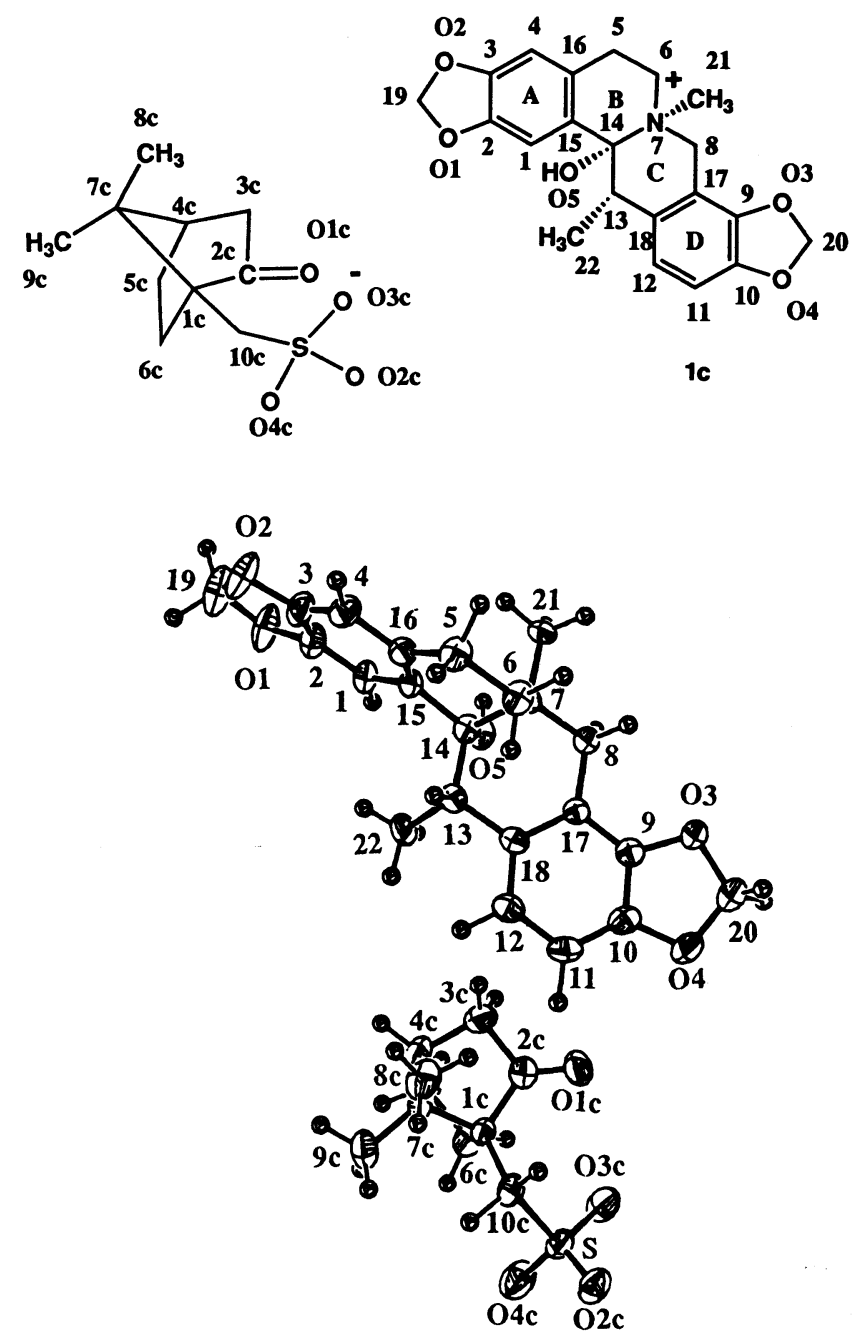

Fig. 1. Molecular structure of (-)-corycavinium (+)-10-camphorsulfonate

The corycavinium (1c) molecule is 5,6,13,13a-tetrahydro-13a-hydroxy-7-methyl$2,3 ; 9,10$-bis(methylenedioxy)- $8 H$-dibenzo[ $a, g]$ quinolizinium. The basic carbocyclic structure of the salt form of corycavine is $B / C$ ring-closed form, namely protopinium form $\mathbf{c}$, consistent with the $\mathrm{X}$-ray analysis of coulteropine hydrobromide [6]. 
The torsion angles along the $B / C$ ring-junction axis $\mathrm{N}(7)-\mathrm{C}(14)$ are shown in Fig. 2. It is noteworthy that the mode of $B / C$ ring junction in corycavinium; i.e., the stereostructure of quinolizidine moiety, has been revealed as cis-configurated, protopinium form $\mathbf{c}_{c i s}$, with the torsion angle $\mathrm{CH}_{3}(21)-\mathrm{N}(7)-\mathrm{C}(14)-\mathrm{OH} 64.7(6)^{\circ}$, whereas coulteropine hydrobromide has a trans-ring junction, protopinium form $\mathbf{c}_{\text {trans }}$, with $c a .180^{\circ}$. The dihedral angle between the mean planes of aromatic rings $A$ and $D$ in the corycavinium molecule is $79.8(2)^{\circ}$. Compared with the angles of protoberberine alkaloids, this value is similar to those for capaurine hydrobromide [10] and capaurimine $p$-bromobenzoate [11], i.e. $70.7^{\circ}$ and $61.6^{\circ}$, respectively, which adopt cis-fused quinolizidine conformation, and differ greatly from the value $25.7^{\circ}$ for canadinium camphorsulfonate [12], in which a trans-quinolizidine skeleton is involved. As for the reason why the crystal structure observed has a cis-quinolizidine system, but not trans, the following can be considered: in the corycavinium (1c) molecule, the $c i s-B / C$-junction can be interpreted as a result of the relief of the steric repulsion due to the existence of the 'peri-interaction' between the bonds $\mathrm{C}(13)-\mathrm{C}(22) \mathrm{H}_{3}$ and $\mathrm{C}(15)-\mathrm{C}(1) \mathrm{H}$, when the molecule adopts trans-junction. Further, it seems that the cis-B/C-quinolizidine conformation of corycavinium (1c) is more reasonable than the trans one, since (-)-corycavine (1a) is chemically converted by ring closure into (-)- $N$-methyl-meso-tetrahydrocorysaminium (4) salt, in which cis-fused quinolizidine has been presumed in the skeleton [8].

The ring $B$ is in a half-chair conformation, and ring $C$ is in a twisted half-chair conformation (Fig. 3). Ring $B$ is much more distorted than ring $C$. Such a twisting might have occurred through moving away from the steric crowd caused by 1,3-diaxial interaction, both between bonds $\mathrm{C}(6)-\mathrm{H}_{\mathrm{ax}}$ and $\mathrm{C}(13)-\mathrm{C}(14)$, and between $\mathrm{C}(6)-\mathrm{H}_{\mathrm{ax}}$ and $\mathrm{C}(8)-\mathrm{C}(17)$.

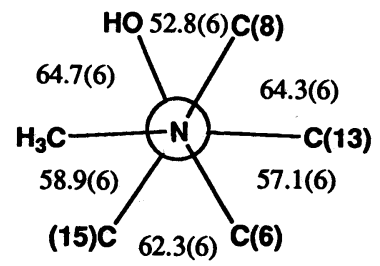

Fig. 2. Torsion angles $\left[^{\circ}\right]$ with standard deviations about the bond $N(7)-C(14)$

a)

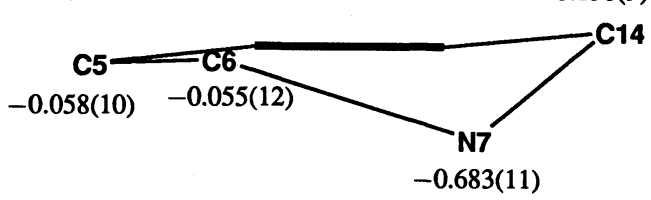

Ring $B$ b)

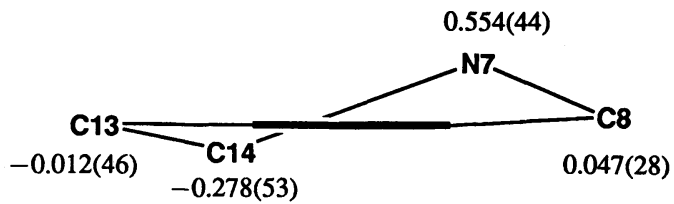

Ring $C$

Fig. 3. Schematic projection of rings $\mathrm{B}$ and $\mathrm{C}$. Deviations of atoms from the least-squares planes of aromatic ring. The thick bar stands for the aromatic ring, indicating ring $A(a)$ and $\operatorname{ring} D(b)$. Deviations in $\AA$, with e.s.d.'s in parentheses. 
Bond lengths and angles appear to be similar to those of related compounds, except for the bond length of $\mathrm{C}(14)-\mathrm{N}(7)$ atoms in corycavinium (1c). While the typical value for $\mathrm{C}-\mathrm{N}^{+}$takes $1.52 \AA$ [13], this distance shows the value $1.583(8) \AA$. This lengthening may be due to strain in the molecule, in which the $C(14), N(7)$ ring closure is somewhat crowded. Particularly the steric factors around $\mathrm{C}(14)$ atom may affect the length. The order of the $\mathrm{C}-\mathrm{N}^{+}$bond length of corycavinium (1c) camphorsulfonate $\left(\begin{array}{ll}1.583 & \AA\end{array}\right)=$ coulteroine $\cdot \mathrm{HBr}(1.58 \AA)<$ capaurimine $\cdot \mathrm{HBr} \quad(1.56 \AA)<$ canadinium camphorsulfonate $(1.53 \AA)$ is proportional to the order of steric hindrance, $\mathrm{HO} \sim \mathrm{C}(14)-\mathrm{N}^{+}-\mathrm{Me} \quad(B / C$ ring junction with angular $\mathrm{OH}$ and $\mathrm{Me}$ groups) $>\mathrm{H} \cdots \mathrm{C}(14)-\mathrm{N}^{+} \cdots \mathrm{H}($ cis $-B / C$-ring junction $)>\mathrm{H} \cdots \mathrm{C}(14)-\mathrm{N}^{+}-\mathrm{H}($ trans $-B / C-$ ring junction).

Fig. 1 depicts the absolute structure of the (-)-form corycavinium (1c) ion relative to the known absolute configuration of $(+)-10$-camphorsulfonate ion, the absolute configuration of which is the same as that determined chemically and crystallographically for $(+)-(1 R, 4 R)$-camphor [14]. Thus, it was proven that the absolute configuration of the (-)-corycavinium (1c) molecule is $(7 S, 13 S, 14 R)$. This agrees with our previous result based on the use of the CD spectral method [8].

The packing diagram of $(-)$-corycavinium $(1 c)(+)$-10-camphorsulfonate is shown in Fig. 4. The shortest distance between anion and cation, 3.799(7) $\AA$, is found from N(7) to $\mathrm{O}(3 \mathrm{c})$. The layers consisting of $(-)$-corycavinium $(\mathbf{1 c})$ cations and of $(+)$-10-camphorsul-

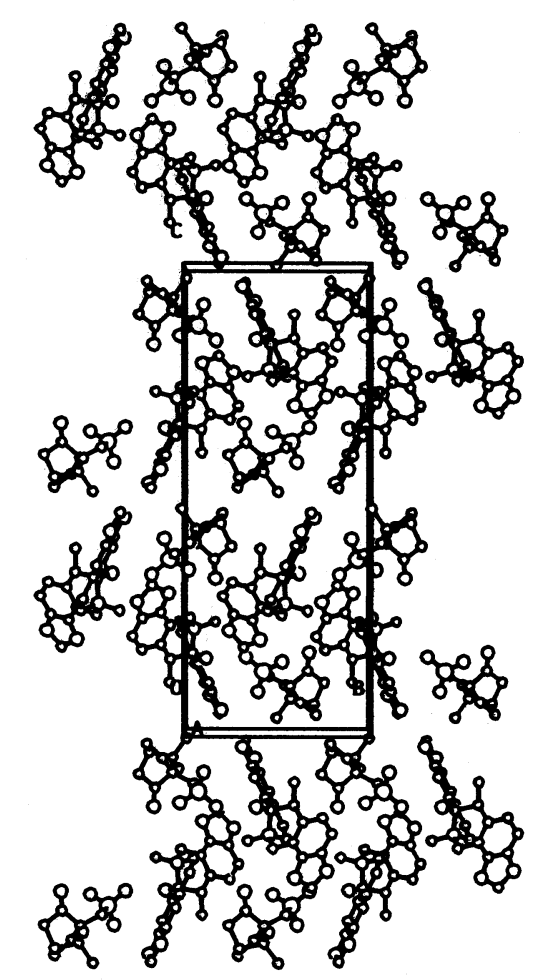

Fig. 4. Crystal packing of the (-)-corycavinium (1c) (+)-10-camphorsulfonate viewed along the a-axis 
fonate anions are alternatively arranged parallel to the $b$-axis. This packing state between the anion and cation molecules is similar to that in (-)-canadinium (+)-10-camphorsulfonate.

Biosynthetic Studies. We report here on a biosynthetic investigation of corycavinium (1c) as a key intermediate in the route from protoberberine-type to hexahydrobenzo[c]phenanthridine-type alkaloids, an investigation using the callus tissues of Corydalis incisa (Papaveraceae). The callus tissues of C.incisa were derived from the stem tissue, and in the suspension cultures the substrates, ${ }^{13} \mathrm{C}$-labelled $( \pm)-N$-methyl-meso-tetrahydrocorysaminium (4) chloride and ( \pm )-corycavinium (1c) chloride, were administered according to the previously described procedure [3]. In Table 1, the results of the feeding experiments are listed.

Table 1. Incorporation Experiments with ${ }^{13} \mathrm{C}$-Labelled Substrates on the Tissue Cultures of C. incisa

\begin{tabular}{lllll}
\hline Exper. & Substrate & \multicolumn{2}{c}{ Conversion yield of metabolic product [\%] } \\
\cline { 3 - 5 } & & $(-)-1$ & $(+)-2$ & $(+)-3$ \\
\hline 1 & $( \pm)-4 \cdot C l$ & 12.7 & 3.3 & 0.3 \\
2 & $( \pm)-4 \cdot C l$ & 15.4 & trace & trace \\
3 & $( \pm)-1 c$ & & 7.5 & 5.6 \\
4 & $( \pm)-1 c$ & 5.5 & 5.0 \\
\hline
\end{tabular}

Exper. 1 and 2 showed that ( \pm )- $N$-methyl-meso-tetrahydrocorysaminium (4) salt was transformed to (-)-corycavine (1a) with a $12.7 \%$ and $15.4 \%$ conversion yield, and to corynoline (2) with $3.3 \%$. In spite of the use of the racemate form, the recovered substrates contained much (+)-enantiomer (optical purity ca. 88-95\%). This implies that only the levorotatory form can be stereospecifically metabolized into corycavine (1a) and corynoline (2).

In Exper. 3 and 4, corycavinium (1c) salt was transformed to corynoline (2) and 14-epicorynoline (3) with a ca. 5-7\% conversion yield.

With these studies, the sequence (-)- $N$-methyl-meso-tetrahydrocorysaminium (4) salt $\Rightarrow(-)$-corycavinium (1c) salt $\Rightarrow$ corynoline (2) and 14-epicorynoline (3) has been described. It has also been determined that 1c plays an important role in the metabolic route (Scheme 2).

Scheme 2. Biogenetic Sequence in Tissue Cultures of Corydalis incisa<smiles>C[C@H]1c2ccc3c(c2C[N+](C)(C)[C@H]1C)OCO3</smiles>

4, (-)-N-methyl-mesotetrahydrocorysaminium

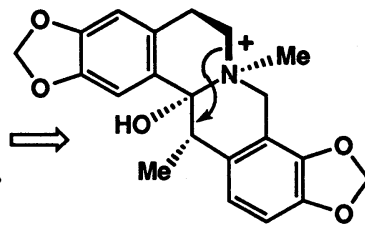

1c, (-)-corycavinium

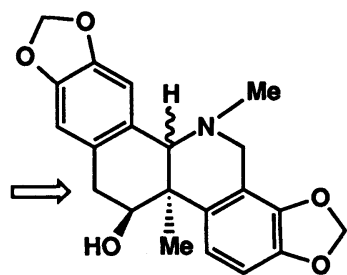

2, (+)-corynoline: $\cdot \cdots \mathrm{H}$ 3, (+)-14-epicorynoline: $-\mathrm{H}$ 
Biosynthetic Implications of the Absolute Configuration and Molecular Conformation of (-)-Corycavinium (1c). It is interesting to speculate about which molecule can stereospecifically interact as a substrate with the enzyme relating to the metabolism. Although there is no direct evidence of the interaction between the molecule and the enzyme, the results obtained by the present study would provide the following hypothesis: $a$ ) The enzyme functions as a hydroxylase with levorotatory enantiomeric specificity in $N$-methyl-meso-tetrahydrocorysaminium (4) salt metabolism. $b$ ) The enzyme introduces the $\mathrm{OH}$ group at $\mathrm{C}(14)$ with the complete retention of the absolute configuration at both $\mathrm{C}(13)$ and $\mathrm{C}(14) . c$ ) After the introduction of the $\mathrm{OH}$ group at $\mathrm{C}(14)$, the cleavage of the bond $\mathrm{C}(6)-\mathrm{N}(7)$ proceeds oxidatively. $d$ ) The process of the new bond formation between atoms $\mathrm{C}(6)$ and $\mathrm{C}(13)$ on the $\beta$-side of the molecule is subjected to the conformationally steric hindrance among the $\alpha$-oriented substituents, $\mathrm{N}(7) \cdots \mathrm{Me}, \mathrm{C}(13) \cdots \mathrm{Me}$, and $\mathrm{C}(14) \cdots \mathrm{OH}$.

Although further clarification of the biosynthetic mechanism of the alkaloids must be subjected to a future, detailed biosynthetic study, from the viewpoint of conformational investigation into the substrate side, the present study provides an efficient approach for a biogenetic study.

\section{Experimental Part}

General. M.p.: Yanagimoto microhotstage apparatus, uncorrected. Optical rotations: DIP-SL (Jasco) polarimeter. IR Spectra: in $\mathrm{KBr}$ or $\mathrm{CHCl}_{3}$, with an EPI-C2 (Hitachi) spectrometer. ${ }^{1} \mathrm{H}-\mathrm{NMR}$ Spectra: in $\mathrm{CDCl}_{3}$ or $\mathrm{CD}_{3} \mathrm{OD}$ soln. with TMS as an internal standard on a Varian-XL $200(200 \mathrm{MHz})$ and a Varian VXR-500 $(500 \mathrm{MHz})$ spectrometer. MS: Jeol-DIS spectrometer.

$X$-Ray Analysis. Material. ( \pm )-Corycavine (1) was isolated from Corydalis incisa and C.cava (Papaveraceae) in the usual way. (-)-Corycavinium (+)-10-camphorsulfonate was prepared according to [8], and single crystals for $\mathrm{X}$-ray study were obtained from $\mathrm{MeOH}$ at r.t.

Crystal-Structure Determination and Refinement. Crystal density was measured by the flotation method using a mixture solvent benzene/bromobenzene. Crystal data for (-)-corycavinium (+)-10-camphorsulfonate is presented in Table 2.

Table 2. Crystal Data of (-)-Corycavinium (+)-10-Camphorsulfonate

\begin{tabular}{ll}
\hline Formula & $\mathrm{C}_{21} \mathrm{H}_{22} \mathrm{O}_{5} \mathrm{~N}^{+} \cdot \mathrm{C}_{10} \mathrm{H}_{15} \mathrm{O}_{4} \mathrm{~S}^{-}$ \\
Mol. wt. & 599.71 \\
M.p. $\left[{ }^{\circ} \mathrm{C}\right]$ & $282-287$ (methanol) \\
Crystal system & orthorhombic \\
Space group & $P 2_{1} 2_{1} 2_{1}$ \\
Cell dimensions & $a=8.294(2) \AA$ \\
& $b=11.625(3) \AA$ \\
& $c=29.096(8) \AA$ \\
$V\left[\AA^{3}\right]$ & $2805(1)$ \\
$F(000)$ & 1272 \\
$\lambda[\AA]$ & 1.5418 \\
$\mu\left[\mathrm{cm}{ }^{-1}\right]$ & 14.77 \\
$Z$ & 4 \\
$D_{x}[\mathrm{~g} \cdot \mathrm{cm}-3]$ & 1.420 \\
$D_{m}\left[\mathrm{~g} \cdot \mathrm{cm}-\mathrm{cm}^{-3}\right]$ & 1.419 \\
No. of measured reflections & 2746 \\
No. of unique reflections & 2732 \\
No. of obs. reflections & 2732 (including $\left.F_{\mathrm{o}}=0.0\right)$ \\
$R$ & 0.067 \\
$R_{w}$ & 0.068 \\
\hline
\end{tabular}


The cell-dimensions and orientation matrix were calculated by the least-squares method from the angular values of 25 reflections collected with an AFC-5 diffractometer (Rigaku Co., Ltd.). The intensities were collected with an $\omega-2 \theta$ scan mode. The intensities of 4 standard reflections, measured every 100 reflections, remained constant within $\pm 1 \%$ of their mean values. The measured intensities within $2 \theta=130^{\circ}$ were then subjected to Lorentz and polarization corrections; absorption correction was also applied, based on the intensity variation of a $(0 k 0)$ reflection for the $ø$ scan at $\chi=90^{\circ}$. The structure was solved by direct methods using the MULTAN Program System [15] and refined by the full-matrix least-squares method with isotropic thermal parameters, and then by the block-diagonal least-squares method with anisotropic ones. The $\mathrm{H}$-atom positions were located from a subsequent difference Fourier map. The function minimized was $\Sigma\left(\left|F_{0}\right|-\left|F_{c}\right|\right)^{2}$ and the discrepancy index $R$ was $0.067 ; S$ ( $=\left[\left(w\left|F_{\mathrm{o}}\right|-\left|F_{c}\right|\right)^{2} /(M-N)\right]^{1 / 2}$, where $M=$ No. of observed reflections and $N=$ No. of variables) was 1.777 . None of the positional parameters shifted more than one-fifth of their standard deviation, and maximum electron density in the final Fourier synthesis was $0.23 \mathrm{e} \cdot \AA^{-3}$. For all crystallographic computations, the UNICS programs [16] were used, and atomic scattering factors were from International Tables for X-Ray Crystallography [17]. All numerical calculations were carried out on an $A C O S$-2020 computer at the Computation Center of Osaka University and on a Micro VAXII computer at Osaka University of Pharmaceutical Sciences.

Callus Culture. The callus were derived in February 1975 from the stem of Corydalis incisa on Murashige and Skoog's medium containing (2,4-dichlorophenoxy)acetic acid $(1 \mathrm{mg} / \mathrm{l})$, kinetin $(0.1 \mathrm{mg} / \mathrm{l})$, yeast extract $(0.1 \%)$, and agar $(1.2 \%)$. The callus tissues were subcultured in the dark every 3 weeks onto the fresh medium at $22^{\circ}$.

Preparation of ( \pm$)-\mathrm{N}-\left[\left({ }^{13} \mathrm{C}\right)\right.$ Methyl $]$-meso-tetrahydrocorysaminium (4) Chloride $(4 \cdot \mathrm{Cl})$. To an acetone soln. $(30 \mathrm{ml})$ of coptisine chloride $(1 \mathrm{~g})$, isolated from Chelidonium majus (Papaveraceae), aq. NaOH soln. (10\%, 12 $\mathrm{ml}$ ) was added, and the mixture was shaken at r.t. for $0.5 \mathrm{~h}$. The acetone layer was separated by a separatory funnel, and evaporated in vacuo to give coptisine-acetone adduct $(940 \mathrm{mg})$ as a yellow crystalline solid. To a soln. of coptisine-acetone adduct $(1 \mathrm{~g})$, MeI $(5 \mathrm{ml})$ was added, and the mixture was kept at $50^{\circ}$ for $4.5 \mathrm{~h}$ in a sealed tube. After cooling, the precipitated crystals (corysaminium iodide $220 \mathrm{mg}$ ) were filtered. The filtrate was concentrated to yield $106 \mathrm{mg}$ of corysaminium iodide. To a soln. of corysaminium iodide (2 g) in $\mathrm{MeOH}(300 \mathrm{ml}), \mathrm{HCl}(35 \%$, $6 \mathrm{ml})$ and $\mathrm{Zn}$ powder $(2 \mathrm{~g})$ were added, and the mixture was kept at $60^{\circ}$ for $6 \mathrm{~h}$. After evaporation of the solvent, $\mathrm{H}_{2} \mathrm{O}(20 \mathrm{ml})$ was added and the aq. soln. adjusted to $\mathrm{pH} c a .9$ (with $28 \% \mathrm{NH}_{4} \mathrm{OH}$ soln.) and extracted with $\mathrm{CHCl}_{3}(2 \times 200 \mathrm{ml})$. The $\mathrm{CHCl}_{3}$ layer was dried $\left(\mathrm{K}_{2} \mathrm{CO}_{3}\right)$ and evaporated to give the mixture $( \pm)$-tetrahydrocorysamine $/( \pm)$-meso-tetrahydrocorysamine as an oil $(1.1 \mathrm{~g})$. The oil was chromatographed on a column of silica gel (benzene $/ 2-50 \%$ gradient $\mathrm{Et}_{2} \mathrm{O}$ ) to give $( \pm)$-tetrahydrocorysamine $(312 \mathrm{mg}$ ) and $( \pm)$-meso-tetrahydrocorysamine $(409 \mathrm{mg})$. To a soln. of $( \pm)$ meso-tetrahydrocorysamine $(1 \mathrm{~g})$ in acetone $(30 \mathrm{ml}),\left[{ }^{13} \mathrm{C}\right] \mathrm{H}_{3} \mathrm{I}(1 \mathrm{~g}, 99 \%$ enrichment; Isotec, USA) was added, and the mixture was kept at $80^{\circ}$ for $3 \mathrm{~h}$ in a sealed tube. After cooling, the precipitated crystals were filtered. The crystalline product was recrystallized from $\mathrm{MeOH}$ to give $( \pm)-\mathrm{N}$ $\left[\left({ }^{13} \mathrm{C}\right)\right.$ Methyl]-meso-tetrahydrocorysaminium iodide as orange needles $(0.92 \mathrm{~g}) .{ }^{1} \mathrm{H}-\mathrm{NMR}\left(\mathrm{CD}_{3} \mathrm{OD}\right): 6.931,6.913$ $(q, J=8.0$, each $1 \mathrm{H}, \mathrm{H}-\mathrm{C}(11), \mathrm{H}-\mathrm{C}(12)) ; 6.830,6.824(s$, each $1 \mathrm{H}, \mathrm{H}-\mathrm{C}(1), \mathrm{H}-\mathrm{C}(4)) ; 6.066\left(s, \mathrm{OCH}_{2} \mathrm{O}\right) ; 6.022$ $\left(d d, J=17.5,1.0, \mathrm{OCH}_{2} \mathrm{O}\right) ; 4.408(d, J=9.5, \mathrm{H}-\mathrm{C}(14)) ; 3.306\left(d, J=145.0, \mathrm{C}(21) \mathrm{H}_{3}\right) ; 3.100(d q, J=9.5,6.9$, $\mathrm{H}-\mathrm{C}(13)) ; 1.458\left(d, J=6.9, \mathrm{C}(22) \mathrm{H}_{3}\right)$.

The iodide $(100 \mathrm{mg})$ was dissolved in $\mathrm{MeOH}$ and the soln. chromatographed on a column of an anionexchange resin (Amberlite $C G-400$, type $1, \mathrm{MeOH} / \mathrm{H}_{2} \mathrm{O}$ ) to give $81 \mathrm{mg}$ of chloride as plates. M.p. $260-270^{\circ}$ $\left(\mathrm{MeOH} / \mathrm{H}_{2} \mathrm{O}\right)$.

Administration of ( \pm )- N- $\left({ }^{13} \mathrm{C}-\mathrm{Methyl}\right)-\mathbf{4} \cdot \mathrm{Cl}$ (Exper. 1$)$. To $( \pm)-\left({ }^{13} \mathrm{C}\right.$-methyl)-4 $\cdot \mathrm{Cl}(80 \mathrm{mg})$, sterilized $\mathrm{H}_{2} \mathrm{O}$ $(30 \mathrm{ml})$ was added, and aliquots of $3 \mathrm{ml}$ of this aq. soln. were poured into 100-ml Erlenmeyer flasks containing callus (5 g, 2-weeks old) in Murashige and Skoog's medium ( $40 \mathrm{ml}$ ). The cultures were incubated in the dark on a rotary shaker $(70 \mathrm{rpm})$ at $24^{\circ}$ for $19 \mathrm{~d}$. The cells and the medium were separated by filtration through a glass filter. The medium $\left(40 \mathrm{ml} \times 10\right.$ ) was adjusted to $\mathrm{pH} c a .8$ (with $5 \% \mathrm{NH}_{4} \mathrm{OH}$ soln.), and extracted with $\mathrm{Et}_{2} \mathrm{O}(300 \mathrm{ml} \times 2)$. The $\mathrm{Et}_{2} \mathrm{O}$ layer was dried $\left(\mathrm{K}_{2} \mathrm{CO}_{3}\right)$ and evaporated to give a tertiary alkaloid fraction from medium $(F r . M-3)$. The fraction was chromatographed by prep. TLC $(\mathrm{MeOH})$ giving $\left({ }^{13} \mathrm{C}\right)$ corycavine $(1 ; 10.1 \mathrm{mg})$. M.p. $135-136^{\circ}\left(\mathrm{Et}_{2} \mathrm{O}\right)$, $[\alpha]_{\mathrm{D}}=-160.0\left(c=1.0, \mathrm{CHCl}_{3}\right)$. IR: $1668(\mathrm{C}=\mathrm{O}) .{ }^{1} \mathrm{H}-\mathrm{NMR}\left(\mathrm{CDCl}_{3}\right): 1.800\left(d, J=124.0, \mathrm{~N}^{13} \mathrm{CH}_{3}\right) . \mathrm{MS}: 162$ (100), $368\left(15, M^{+}\right)$.

The aq. soln. was adjusted to $\mathrm{pH} c a .4(35 \% \mathrm{HCl}$ soln. $)$, $\mathrm{KI}(3 \mathrm{~g})$ was added and the soln. extracted with $\mathrm{CHCl}_{3}$. The $\mathrm{CHCl}_{3}$ layer was washed with $\mathrm{Na}_{2} \mathrm{~S}_{2} \mathrm{O}_{3}$ soln. $(10 \%)$ and then with sat. $\mathrm{NaCl}$ soln., dried $\left(\mathrm{MgSO}_{4}\right)$, and evaporated in vacuo giving a quaternary-alkaloid fraction from medium (Fr.M-4). This fraction was chromatographed on a column of alumina (acetone $/ \mathrm{MeOH})$ to give $\left({ }^{13} \mathrm{C}\right.$-methyl $)-4$ iodide $(2 \mathrm{mg}) .[\alpha]_{\mathrm{D}}=+87.0$ $(c=0.4, \mathrm{MeOH})$. 
The cells (fresh weight $80 \mathrm{~g}$ ) were suspended in $\mathrm{MeOH}(500 \mathrm{ml})$ and extracted on a heating bath for $6 \mathrm{~h}$. The suspension was filtered and the cells re-extracted in $\mathrm{MeOH}(2 \times 200 \mathrm{ml})$. The extracts were then combined and evaporated in vacuo and the residue was extracted with tartaric-acid soln. $(3 \%, 2 \times 150 \mathrm{ml})$. This acid layer was washed with $\mathrm{Et}_{2} \mathrm{O}(2 \times 150 \mathrm{ml})$, and its $\mathrm{pH}$ adjusted to $c a .9$ (with $15 \% \mathrm{NH}_{4} \mathrm{OH}$ soln.). The alkaline soln. was extracted with $\mathrm{Et}_{2} \mathrm{O}(2 \times 200 \mathrm{ml})$. The combined $\mathrm{Et}_{2} \mathrm{O}$ layer was dried $\left(\mathrm{K}_{2} \mathrm{CO}_{3}\right)$ and evaporated to give an oily residue (14 mg, tertiary-alkaloid fraction $(F r . C-3)$ ). This fraction was chromatographed by prep. TLC (benzene/ $\mathrm{Et}_{2} \mathrm{O} 1: 1$, and $\left.\mathrm{MeOH}\right)$ to give ${ }^{13} \mathrm{C}$-corycavine $(1 ; 0.5 \mathrm{mg}),{ }^{13} \mathrm{C}$-corynoline $\left(2 ; 2.0 \mathrm{mg} ;{ }^{1} \mathrm{H}\right.$-NMR $\left(\mathrm{CDCl}_{3}\right): 2.17(d$, $\left.J=140, \mathrm{~N}^{13} \mathrm{CH}_{3}\right)$; MS: $\left.43(100), 368\left(18, M^{+}\right)\right)$, and ${ }^{13} \mathrm{C}$-14-epicorynoline $\left(3 ; 0.2 \mathrm{mg} ;{ }^{1} \mathrm{H}-\mathrm{NMR}\left(\mathrm{CDCl}_{3}\right): 2.47(d\right.$, $\left.J=140 \mathrm{~Hz}, \mathrm{~N}^{13} \mathrm{CH}_{3}\right)$; MS: $\left.43(100), 368\left(14, M^{+}\right)\right)$. The quaternary-alkaloid fraction from callus $(F r . C-4)$ gave $\left({ }^{13} \mathrm{C}\right.$-methyl)-4 I $\left(17.1 \mathrm{mg} ;[\alpha]_{\mathrm{D}}=+146.0(c=1.0, \mathrm{MeOH})\right)$.

Administration of $\mathrm{N}-\left({ }^{13} \mathrm{C}-\mathrm{Methyl}\right)-\mathbf{4} \cdot \mathrm{Cl}($ Exper. 2$)$. Callus $(160 \mathrm{~g})$ was incubated with $( \pm)-\mathrm{N}-\left({ }^{13} \mathrm{C}-\mathrm{methyl}\right)$ 4. $\mathrm{Cl}(160 \mathrm{mg})$ for $10 \mathrm{~d}$. The cells and medium were treated as described above. From $\mathrm{Fr} . \mathrm{M}-3$ and $C-3:{ }^{13} \mathrm{C}$-corycavine $\left(1 ; 25.7 \mathrm{mg} ;[\alpha]_{\mathrm{D}}=-149.0\left(c=1.0, \mathrm{CHCl}_{3}\right)\right)$.

Preparation of $( \pm)-\left(22-{ }^{13} \mathrm{C}\right)$ Corycavinium Chloride $\left(\left(22-{ }^{13} \mathrm{C}\right)-1 \mathrm{c} \cdot \mathrm{Cl}\right)$. The corycavine $(\mathbf{1})$ fraction $(60 \mathrm{mg})$ obtained from administration experiments with $( \pm)-N-\left({ }^{13} \mathrm{C}\right.$-methyl)-4 $\cdot \mathrm{Cl}$ was dissolved in a mixture of $\mathrm{MeOH}$ $(50 \mathrm{ml})$ and $\mathrm{NaOH}$ soln. $\left(5 \%, 2\right.$ drops) and stirred at $40^{\circ}$. After $1 \mathrm{~h}$, the soln. was evaporated in vacuo, and $\mathrm{CHCl}_{3}$ $(40 \mathrm{ml})$ was added. The $\mathrm{CHCl}_{3}$ layer was washed with sat. $\mathrm{NaCl}$ soln., dried $\left(\mathrm{Na}_{2} \mathrm{SO}_{4}\right)$, and evaporated to give $57 \mathrm{mg}$ of $( \pm)-\left(22-{ }^{13} \mathrm{C}\right)-1 \mathrm{a}$, as prisms. M.p. $217.0-218.0^{\circ}(\mathrm{MeOH}) .( \pm)-\left(22-{ }^{13} \mathrm{C}\right)-1$ a was dissolved in sterilized $\mathrm{H}_{2} \mathrm{O}$ $(30 \mathrm{ml})$, and the soln. made acidic (with $5 \% \mathrm{HCl}$ soln.).

Administration of $( \pm)-\left(22-{ }^{13} \mathrm{C}\right)-\mathbf{1 c}($ Exper. 3$)$. Callus $(80 \mathrm{~g})$ was incubated with $( \pm)-\left(22-{ }^{13} \mathrm{C}\right)-\mathbf{1 c} \cdot \mathrm{Cl}(32 \mathrm{mg})$ for $7 \mathrm{~d}$. The cells and medium were treated as described above. From Fr. M-3 and C-3: ${ }^{13} C$-corynoline $(2 ; 2.4 \mathrm{mg}$; $\left.[\alpha]_{\mathrm{D}}=+80\left(c=0.5, \mathrm{CHCl}_{3}\right)\right),{ }^{13} C$-14-epicorynoline $\left(3 ; 1.8 \mathrm{mg} ;[\alpha]_{\mathrm{D}}=+110\left(c=0.20, \mathrm{CHCl}_{3}\right)\right)$. From Fr.M-3:

${ }^{13} C$-corycavine $\left(1 ; 8.1 \mathrm{mg} ;[\alpha]_{\mathrm{D}}=-40\left(c=1.0, \mathrm{CHCl}_{3}\right)\right)$. From Fr. $C$-3: ${ }^{13} C$-corycavine $\left(1 ; 1.5 \mathrm{mg}:[\alpha]_{\mathrm{D}}=-80\right.$ $\left.\left(c=0.2, \mathrm{CHCl}_{3}\right)\right)$.

Administration of $( \pm)-\left(22-{ }^{13} \mathrm{C}\right)-\mathbf{1 c} \cdot \mathrm{Cl}$ (Exper.4). Callus $(80 \mathrm{~g})$ was incubated with $( \pm)-\left(22-{ }^{13} \mathrm{C}\right)-\mathbf{1 c} \cdot \mathrm{Cl}$ $\left(20 \mathrm{mg}\right.$ ) for $12 \mathrm{~d}$. The cells and medium were treated as described above. From $\mathrm{Fr} . M-3$ and $C-3:{ }^{13} C$-corynoline (2; $\left.1.1 \mathrm{mg} ;[\alpha]_{\mathrm{D}}=+65.0\left(c=0.2, \mathrm{CHCl}_{3}\right)\right),{ }^{13} \mathrm{C}$-14-epicorynoline $\left(3 ; 1.0 \mathrm{mg} ;[\alpha]_{\mathrm{D}}=+34.0\left(c=0.2, \mathrm{CHCl}_{3}\right)\right)$.

Atomic coordinates have been deposited at the Cambridge Crystallographic Data Centre.

\section{REFERENCES}

[1] A. Brossi, 'The Alkaloids,' Academic Press, London, 1988, Vol. 34, pp. 181-209.

[2] N. Takao, K. Iwasa, M. Kamigauchi, M. Sugiura, Chem. Pharm. Bull. (Tokyo) 1976, 24, 2859.

[3] N. Takao, M. Kamigauchi, M. Okada, Helv. Chim. Acta 1983, 66, 473.

[4] K. Iwasa, M. Kamigauchi, N. Takao, M. Cushman, W. Wong, J. Chen, Tetrahedron Lett. 1988, $29,6457$.

[5] K. Iwasa, M. Kamigauchi, T. Takao, J. Nat. Prod. 1988, 51, 1232.

[6] F. R. Stermitz, R. M. Coomes, D. R. Harris, Tetrahedron Lett. 1968, 9, 3915.

[7] M. Kamigauchi, K. Iwasa, N. Takao, T. Ishida, M. Inoue, Helv. Chim. Acta 1987, 70, 1482.

[8] M. Kamigauchi, Y. Noda, K. Iwasa, N. Takao, W. Wiegrebe, Arch. Pharm. (Weinheim) 1992, $325,585$.

[9] M. Kamigauchi, Y. Noda, K. Iwasa, Z. Nishijo, N. Takao, T. Ishida, Y. In, M. Inoue, Arch. Pharm. (Weinheim) 1993, 326, 501.

[10] H. Shimanouchi, Y. Sasada, M. Ihara, T. Kametani, Acta Crystallogr., Sect. B 1969, 25, 1310.

[11] T. Kametani, M. Ihara, T. Honda, H. Shimanouchi, Y. Sasada, J. Chem. Soc. (C) 1971, 2541.

[12] T. Sakai, Z. Taira, M. Kamigauchi, N. Takao, Acta Crystallogr., Sect. C 1987, 43, 98.

[13] J. A. Hamilton, T. A. Hamor, J. M. Robertson, G. A. Sim, J. Chem. Soc. 1962, 5061.

[14] W. Klyne, J. Buckingham, 'Atlas of Stereochemistry', 'Absolute Configurations of Organic Molecules', Chapman and Hall, London, 1978, Vol. 1, pp. 85-86.

[15] P. Main, S. E. Hull, L. Lessinger, G. Germain, J.P. Declercq, M. M. Woolfson, 'MULTAN 78, A System of Computer Programs for the Automatic Solution of Crystal Structures from X-Ray Differaction Data', Universities of York and Louvain, Belgium, 1978.

[16] T. Ashida, 'The Universal Crystallographic Computing System Osaka', Library of Programs, Computing Center, Osaka Univ., 1979.

[17] J.A.Ibers, W.C. Hamilton, 'International Tables for X-Ray Crystallography', Kynoch Press, Birmingham, 1974, Vol. 4. 